\title{
Effects of mimosine administered to a perfused area of skin in Angora goats
}

\author{
BY R. PUCHA£A, S. G. PIERZYNOWSKI, T. SAHLU* AND S. P. HART \\ E. (Kika) de la Garza Institute for Goat Research, Langston University, Langston, \\ Oklahoma 73050, USA
}

(Received 11 November 1994 - Revised 15 March 1995-Accepted 11 May 1995)

\begin{abstract}
The effect of mimosine on a perfused area of skin tissue was studied using an isolated perfusion technique. Four mature Angora wethers (body weight 35 (SE 2-3) kg) were cannulated bilaterally with indwelling silicone catheters in the superficial branches of the deep circumflex iliac artery and vein. Mimosine $\left(40 \mathrm{mg} / \mathrm{kg}\right.$ metabolic weight $\left(\mathrm{W}^{0775}\right)$ per $\left.\mathrm{d}\right)$ was infused intra-arterially into one iliac artery of each goat for $3 \mathrm{~d}$ and saline was infused in the contralateral (control) iliac artery. Iliac venous blood samples were taken from both sides along with arterial samples from the carotid artery. Mimosine infusion elevated plasma mimosine in the carotid artery (52.6 (SEM 19.21) $\mu \mathrm{mol} / \mathrm{l})$ and iliac vein on the saline-treated side to 54.1 (SEM 16.31) $\mu \mathrm{mol} / \mathrm{l}$ and in the iliac vein on the mimosine-treated side to $191 \cdot 3$ (SEM 19.14) $\mu \mathrm{mol} / 1$ $(P<0.01)$. Mimosine decreased feed intake $(2.3$ v. $0.6 \mathrm{~kg} / \mathrm{d}$, SEM $0.29 ; P<0.001)$ and water consumption (5.2 v. 1.3 litres/d, SEM 0.67; $P<0.001)$. Mimosine did not cause defleecing in the area of infusion and was cleared from the bloodstream within $12 \mathrm{~h}$ of cessation of infusion. The following effects were also observed during mimosine infusion: decrease in plasma amino acids to half pre-infusion values (methionine $22.7 v .13 .1 \mu \mathrm{mol} / 1$, SEM 1.41; lysine 95.9 v. 37.4 $\mu \mathrm{mol} / \mathrm{l}$, SEM 4.28; $P<0.001$ ); decreases in plasma triiodothyronine (1495 v. $695 \mathrm{ng} / \mathrm{l}$, SEM $43.1 ; P<0.001)$, thyroxine $(61.5 v .19 .5 \mu \mathrm{g} / \mathrm{l}$, SEM 1.8; $P<0.001)$ and insulin $(28.7 v .17 .3 \mu \mathrm{IU} / \mathrm{ml}$, SEM 1.89; $P<0.01)$ concentrations; increase in plasma cortisol (14 v. $62 \mu \mathrm{g} / \mathrm{l}$, SEM 0.35; $P<0.001)$ concentration; decreases in levels of plasma $\mathrm{Zn}$ and $\mathrm{Mg}$ (0.97 v. 0.49 mg/l, SEM 0.063; $P<0.001$ and 21.4 v. $14.6 \mathrm{mg} / \mathrm{l}$, SEM 1.74; $P<0.001$ respectively). All reported variables returned to their normal values $24 \mathrm{~h}$ after cessation of mimosine infusion except feed intake which was affected for a longer period. Mohair length and diameter were not affected by mimosine infusion. The toxicity of mimosine may be due to the drastic depletion of $\mathrm{Zn}$ and $\mathrm{Mg}$ in the blood as mimosine possesses very strong chelating properties and is excreted in the urine as a chelate.
\end{abstract}

Angora goats: Mimosine: Skin perfusion

Mimosine ( $\beta$-( $N$-(3-hydroxy-4-oxopyridyl))- $\alpha$-aminopropionic acid) is a naturally occurring toxic amino acid found in the seeds and leaves of Leucaena leucocephala. Several explanations concerning the mode of action of mimosine toxicity have been presented. Its similarity in structure to tyrosine and phenylalanine has led to the conclusion that it replaces these amino acids in proteins and enzymes (Thompson et al. 1969; Hegarty, 1978). Such replacement causes loss of enzyme and functional protein activity. El-Harith et al. (1983) have proposed a model in which the toxic effect of mimosine is explained by a deficiency of glycine for synthesis of bile acids, which in turn causes a decrease in fatty acid absorption thereby causing a deficiency of fat-soluble vitamins. A direct effect of mimosine on DNA and RNA polymerases was postulated by Reisner et al. (1979). Inhibition of DNA synthesis due to mimosine was observed in different cells by Ward \& Harris (1976) and Hegarty et al. (1978). Complexing of mimosine with pyridoxal phosphate was given as a possible explanation of mimosine toxicity (Thompson et al. 1969; Hegarty, 1978). Lack of

\footnotetext{
* For reprints.
} 
pyridoxal coenzymes causing inhibition of many enzymes linked to amino acid metabolism, such as cystathionine $\gamma$-lyase (EC 4.4.1.1; Unterhalt, 1980) and tyrosine decarboxylase (EC 4.1.1.25; Crounse et al. 1962), has also been reported. Another possible factor in mimosine toxicity is the inhibition of superoxidase dismutases such as succinate dehydrogenase (EC 1.3.5.1; Tsai, 1961) and alkaline phosphatase (EC 3.1.3.1; ElHarith et al. 1981).

Changes in wool growth and other variables have been observed in animals fed on diets high in mimosine. Szyszka \& Meulen (1985) reported that there were no signs of mimosine poisoning when sheep were fed on diets containing Leucaena leaf $(0.14 \mathrm{~g}$ mimosine $/ \mathrm{kg}$ body weight (BW)); however, the animals subsequently cast their fleece. When sheep were fed on a diet containing 300 or $600 \mathrm{~g}$ Leucaena $/ \mathrm{kg}$ (providing 0.13 or $0.26 \mathrm{~g}$ mimosine $/ \mathrm{kg} \mathrm{BW}$ per d), fleece loss was observed after $10 \mathrm{~d}$ of continuous feeding but no differences were noted between the two treatments (Franzolin \& Velloso, 1986). Ward \& Harris (1976) demonstrated inhibition of DNA synthesis in vitro in sheep wool follicle bulb cells. Mimosine was investigated as a potential defleecing agent in Australia. Reis (1978) observed that intravenous infusion of mimosine at the rate of $80 \mathrm{mg} / \mathrm{kg} \mathrm{BW}$ per din sheep for $2 \mathrm{~d}$ produced consistent defleecing. It could be concluded, therefore, that mimosine toxicity affects skin metabolism and wool growth very quickly and changes in wool growth are the first visible symptoms of mimosine toxicity. Thus, the possibility exists that a particular area of skin infused with mimosine would show differences when compared with an area infused with saline. If mimosine changes skin metabolism directly, changes in blood variables are also expected.

The objective of the present study was to investigate whether there was a local effect of mimosine on blood metabolites and fibre growth using a skin perfusion model developed in our laboratory.

\section{MATERIALS AND METHODS}

Animals and surgery

Four Angora wethers (body weight (BW) 35 (SE 2.3) kg) from the research herd of E. (Kika) de la Garza Institute for Goat Research were used in the present study. Animals were anaesthetized with ketamine hydrochloride $(20 \mathrm{mg} / \mathrm{kg} \mathrm{BW}$; Ketaset, Aveco Co., Fort Dodge, IA, USA) and implanted bilaterally with silicone catheters in the superficial branches of the deep circumflex iliac artery (i.d. $0.3 \mathrm{~mm}, 0 . \mathrm{d} .0 .63 \mathrm{~mm}$ ) and in the deep circumflex iliac vein (i.d. $0.51 \mathrm{~mm}$, o.d. $0.94 \mathrm{~mm}$ ) as described by Pierzynowski et al. (1994). An indwelling catheter was inserted into the carotid artery. Animals recovered from anaesthesia within 5-6 h and were moved to individual cages where they were allowed to recover for 1 week. For the experimental period the animals were offered a complete mixed diet (110 g crude protein and $10 \mathrm{MJ}$ metabolizable energy $/ \mathrm{kg} \mathrm{DM}$ ). Animals were fed $\mathrm{ad}$ $l i b$. once daily at 08.00 hours, and had free access to water.

\section{Experimental procedures}

Experimental design. The experiment was divided into five periods. On day 1 blood was collected from all three catheters to determine initial levels of metabolites (pre-infusion control period, PRC; -36 and $-24 \mathrm{~h})$. On day 2 saline $(9 \mathrm{~g} \mathrm{NaCl} / 1 ; 10 \mathrm{ml} / \mathrm{h})$ was infused bilaterally to the deep circumflex iliac artery and blood was taken twice (pre-infusion saline period, PRS; -12 and $0 \mathrm{~h})$. On days $3-5$ mimosine $\left(40 \mathrm{mg} / \mathrm{kg}\right.$ metabolic weight $\left(\mathrm{W}^{0.75}\right)$ per d) diluted in saline was infused at a rate of $10 \mathrm{ml} / \mathrm{h}$ to the deep circumflex iliac artery in the treated side. The control side received saline at the same rate of $10 \mathrm{ml} / \mathrm{h}$. Blood was collected twice daily during the mimosine period (MI; 12, 24, 36, 48, 60 and $72 \mathrm{~h}$ ). Following cessation of mimosine infusion on day 5 (post-infusion saline period, PSS) all goats 
continued to receive the saline bilaterally and blood samples were collected at 84 and $96 \mathrm{~h}$. On days 7 and 8 of the experiment, post-infusion control (PSC) blood samples were collected (108 and $136 \mathrm{~h}$ ). At 3 weeks after cessation of infusion a mohair sample from the perfused region was collected for analysis of fibre length and diameter. At the same time the perfused areas were checked to determine if mohair could be removed by hand.

Materials. The mimosine used was from Koa hoale seed and was $99 \%$ pure (Sigma Chemical Company, St Louis, MO, USA). The infusions were performed using microinfusion pumps (Siropump, Everest Electronic, Seaford, Australia).

Blood collection. Blood samples were collected from both treated (mimosine infusion) and control (saline infusion) catheterized deep circumflex iliac veins as well as from the carotid artery (peripheral blood). Blood was collected into $7 \mathrm{ml}$ capacity tubes containing either potassium oxalate and $\mathrm{NaF}$ or sodium heparin or $\operatorname{EDTA}\left(\mathrm{K}_{3}\right)$ (Becton Dickinson Vacutainer Systems, Rutherford, NJ, USA). The tubes were immediately chilled in an ice bath and transported to the laboratory where they were centrifuged at $1500 \mathrm{~g}$ at $4^{\circ}$ for $20 \mathrm{~min}$. Plasma samples were stored at $-20^{\circ}$ until analysis.

Analyses. Plasma hormones were analysed using commercially available kits from ICN Biomedicals, Inc. (Costa Mesa, CA, USA); insulin (Cat. No. 07-160102), cortisol (Cat. No. 07-221102), total triiodothyronine $\left(T_{3}\right)$ (Cat. No. 07-292102) and total thyroxine $\left(\mathrm{T}_{4}\right.$ ) (Cat. No. 07-290102). The intra-assay $\mathrm{CV}$ averaged $10 \cdot 3 \%$ for insulin, $7.68 \%$ for cortisol, $6.6 \%$ for $\mathrm{T}_{3}$ and $5.9 \%$ for $\mathrm{T}_{4}$. Amino acid analyses were performed using AminoQuant (Hewlett Packard, San Fernando, CA, USA) using precolumn derivatization with 0 -phthalaldehyde and 9-fluorenylmethylchloroformate and u.v. detection. Plasma $(1 \mathrm{ml})$ with added internal standard (norvaline and sarcosine, $0.1 \mathrm{ml}$ ) was deproteinized with $0.9 \mathrm{ml}$ Seraprep (Pickering, Mountain View, CA, USA). Plasma mimosine was estimated using a HPLC method described by Tangendjaja \& Wills (1980). Plasma Zn, Mg, $\mathrm{Fe}$ and $\mathrm{Cu}$ concentrations were estimated using plasma emission spectroscopy (Applied Research Laboratories, Inc., Dearborn, MI, USA), according to the method of Seeley \& Kinsey (1982). Plasma glucose concentrations were analysed colorimetrically using a Sigma glucose diagnostic kit (Cat. No. 315 Sigma Diagnostic, St Louis, MO, USA). Plasma nonesterified fatty acid (NEFA) concentration was analysed using a Wako NEFA test kit that utilizes an enzymic method for the quantification of non-esterified (or free) fatty acids (Wako Pure Chemical Industries, Osaka, Japan; Cat. No. 990-75401). Plasma creatinine was estimated using a creatinine diagnostic kit (Cat. No. 555-A, Sigma Diagnostic) and total protein by diagnostic kit (Cat. No. P6529, Sigma Diagnostic). Plasma urea N was determined as described by Sahlu et al. (1992). Fibre length was determined according to American Society for Testing and Materials (1988) standards and fibre diameter was determined using the Peyer FDA 200 System (Wallerau, Switzerland).

\section{Statistical analysis}

Statistical analysis of the data indicated that there was no local effect of mimosine on the skin, except for mimosine concentration. However, there was a systemic animal effect. Therefore the data were analysed for these effects using only the data from the treated side. Data were analysed by ANOVA with single degree of freedom contrasts (Statistical Analysis Systems, 1985). The model used for analysis of most variables included animal and period and the interaction of animal and period which was used as the error term. The first contrast tested for differences between the PRC and PRS periods respectively. When there were no differences between these two periods they were combined and contrasted against the MI period. To test the carry-over effects the PSS period was contrasted with the PRC and PRS periods. To test if the animals had recovered by $36 \mathrm{~h}$ after mimosine infusion the PSC period was contrasted with PRC and PRS periods. The data for plasma mimosine 
concentrations were analysed as a split-plot design. Mohair data were analysed as a randomized complete block design where animals were blocks and side of the animals treatment (Steel \& Torrie, 1980).

\section{RESULTS AND DISCUSSION}

Mimosine infusion (from 0 to $72 \mathrm{~h}$ ) increased plasma mimosine concentration $(P<0 \cdot 01)$ in the iliac vein on the mimosine-treated side above that in both the iliac vein on the control side and the carotid artery (Fig. 1). Mimosine was cleared from the bloodstream within $12 \mathrm{~h}$ of cessation of mimosine infusion. Szyszka \& Meulen (1984) reported that $60 \%$ of ingested mimosine was excreted in the urine within $8 \mathrm{~h}$ in rats, suggesting that very little mimosine metabolism occurs in the cells. Mosca et al. (1992) using a CHOC 400 cell line culture demonstrated that cellular uptake of mimosine is slow. They concluded that either a lag time is required to convert mimosine to an active form capable of inhibiting cell function or that mimosine is not directly involved in cell metabolism.

In the present experiment plasma mimosine concentration in the iliac vein on the mimosine-treated side (Fig. 1) was higher than that reported in peripheral blood of Merino sheep infused systemically with mimosine for $2 \mathrm{~d}(100 \mu \mathrm{mol} / 1$; Reis, 1978). Reis (1978) observed that wool growth ceased approximately $1 \mathrm{~d}$ following the onset of infusion and that the sheep were then able to be manually defleeced. In the present study mimosine did not influence mohair growth even though it was infused for $3 \mathrm{~d}$. Mohair length and diameter were not affected as a result of mimosine infusion (Table 1), and were similar to values for this time of the year and period of growth observed by Puchała et al. (1995a). This indicates that Angora goats respond differently to mimosine from Merino sheep. Hoey \& Hopkins (1983), using sheep cannulated in the retrograde fashion to the deep circumflex iliac arteries, reported that wool was readily plucked by hand from skin preparations infused for $2 \mathrm{~d}$ with $0.6 \mathrm{~g}$ mimosine/d. These authors reported that the depilatory effect was observed only for the skin preparation area and suggested that mimosine affected the area directly.

In the present experiment mimosine infusion decreased feed and water consumption (Table 2). The goats refused feed on the third day of mimosine infusion but regained their appetite $3 \mathrm{~d}$ after cessation of mimosine infusion. Water consumption was similarly affected. Water consumption decreased faster than feed consumption, but at no time did water intake cease completely. Feed and water intake was lowest during the MI and PSS periods. Feed intake in sheep was also decreased by mimosine infusion (Hegarty, 1978); however, the infusion rate was four times higher than in the present experiment.

During the MI and PSS periods plasma glucose concentration increased and corresponded to an increase in plasma NEFA (Table 3). It is difficult to explain the simultaneous increase in these metabolites and why plasma glucose was elevated in goats with depressed feed intake. Plasma NEFA levels remained elevated during the PSC period. Plasma $T_{3}$ and $T_{4}$ concentrations declined during MI (Table 4). These results are in agreement with the work of Jones \& Hegarty (1984), but in contrast to the reports of Jacquement et al. (1990) and Fernandez et al. (1991). Plasma amino acid concentrations decreased during MI with the exception of phenylalanine. In most cases the decrease was twofold or greater (Table 5; Fig. 2). Although animals refused to eat only on the third day of mimosine infusion, changes in blood metabolites were observed much earlier (Table 5; Figs. 2 and 3). Following cessation of mimosine infusion, concentrations of plasma amino acids returned to pre-infusion levels much faster (PSS period) than feed intake (PSC period). Changes in amino acid concentrations cannot be totally attributed to reduced feed intake since they returned to pre-infusion concentrations before resumption of feed intake. 


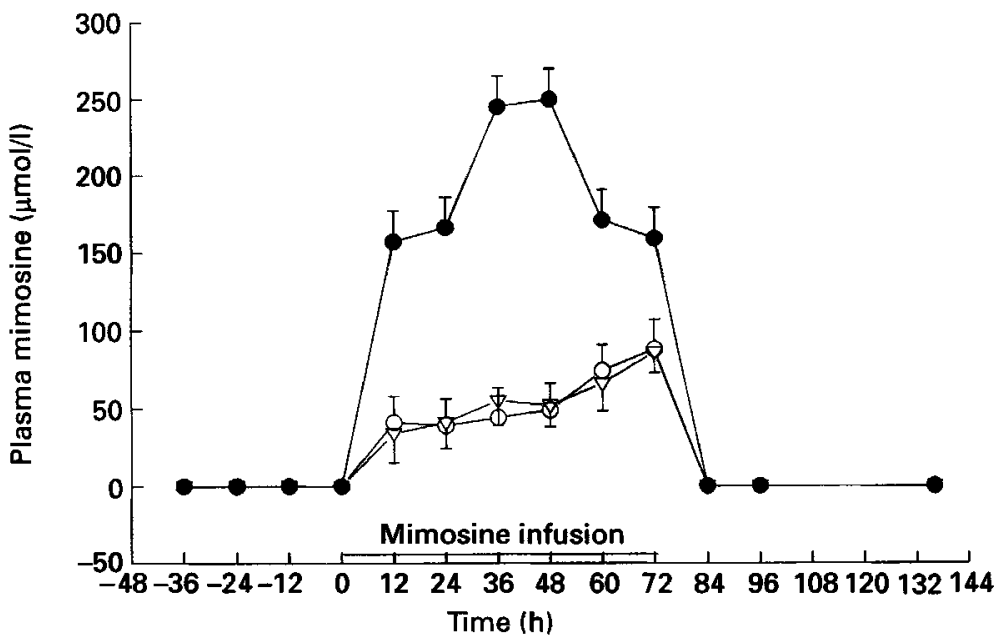

Fig. 1. Plasma mimosine concentration $(\mu \mathrm{mol} / \mathrm{l})$ during mimosine infusion $\left(40 \mathrm{mg} / \mathrm{kg} \mathrm{W}^{0.75}\right.$ per $\left.\mathrm{d}\right)$ to the superficial branch of the deep circumflex iliac artery of Angora goats. Values are means for four goats, with their standard errors indicated by vertical bars. Values for the treated side (O) differed significantly from those of the control side $(O)$ and carotid artery $(\nabla)$ throughout the mimosine infusion $(P<0.01)$.

Table 1. Mohair measurements from skin preparations in Angora goats after $21 d$ cessation of mimosine infusion*

(Mean values for four goats, and the pooled standard error of the mean)

\begin{tabular}{|c|c|c|c|c|}
\hline \multirow[b]{2}{*}{ Item } & \multicolumn{2}{|c|}{ Infusion } & \multirow[b]{2}{*}{ SEM } & \multirow{2}{*}{$\begin{array}{c}\text { Statistical } \\
\text { significance }\end{array}$} \\
\hline & Mimosine & Saline & & \\
\hline \multicolumn{5}{|l|}{ Mohair } \\
\hline Length (mm) & 16.0 & $16 \cdot 0$ & 0.36 & NS \\
\hline Diameter $(\mu \mathrm{m})$ & $28 \cdot 7$ & $29 \cdot 0$ & 0.80 & NS \\
\hline
\end{tabular}

* Total area of the skin supplied by the superficial branch of the deep circumflex iliac artery was about $300 \mathrm{~cm}^{2}$, an area of $50 \mathrm{~cm}^{2}$ located in the middle of perfused region was used for mohair measurements. Mimosine $\left(40 \mathrm{mg} / \mathrm{kg} \mathrm{W}^{0.75}\right.$ per d) was infused intra-arterially into one iliac artery of each goat for $3 \mathrm{~d}$ and saline was infused in the contralateral (control) iliac artery.

Table 2. Feed and water intake by Angora goats during mimosine infusion*

(Mean values for four goats with the pooled standard error of the mean)

\begin{tabular}{|c|c|c|c|c|c|c|c|c|c|c|}
\hline \multirow[b]{3}{*}{ Item } & & & \multirow[b]{3}{*}{ MI } & & & \multirow[b]{3}{*}{ SEM } & \multicolumn{4}{|c|}{ Contrast } \\
\hline & \multicolumn{2}{|c|}{ Pre } & & \multicolumn{2}{|c|}{ Post } & & \multirow{2}{*}{$\begin{array}{c}\text { PRC } \\
v . \\
\text { PRS }\end{array}$} & \multirow{2}{*}{$\begin{array}{c}\text { PRC } \\
+ \text { PRS } \\
v . \\
\text { MI }\end{array}$} & \multirow{2}{*}{$\begin{array}{c}\text { PRC } \\
+ \text { PRS } \\
v . \\
\text { PSS }\end{array}$} & \multirow{2}{*}{$\begin{array}{c}\text { PRC } \\
+ \text { PRS } \\
v . \\
\text { PSC }\end{array}$} \\
\hline & PRC & PRS & & PSS & PSC & & & & & \\
\hline Feed $(\mathrm{kg} / \mathrm{d})$ & $2 \cdot 3$ & $2 \cdot 3$ & $1 \cdot 1$ & 0.6 & 1.8 & $0 \cdot 29$ & NS & 0.001 & 0.001 & NS \\
\hline Water (litres/d) & $5 \cdot 0$ & $5 \cdot 2$ & $2 \cdot 1$ & $1 \cdot 3$ & 3.7 & 0.67 & NS & 0.001 & 0.001 & NS \\
\hline
\end{tabular}

PRC, pre-infusion control $(-36,-24 \mathrm{~h})$; PRS, pre-infusion saline $(-12,0 \mathrm{~h})$; MI, mimosine infusion (12-72 h); PSS, post-infusion saline (84-96 h); PSC, post-infusion control (108, $136 \mathrm{~h})$.

* Infusion of mimosine $\left(40 \mathrm{mg} / \mathrm{kg} \mathrm{W}^{0 \cdot 75}\right.$ per $\mathrm{d}$ ) to the superficial branch of the deep circumflex iliac artery was started at $0 \mathrm{~h}$ and ceased at $72 \mathrm{~h}$. 
Table 3. Concentration of plasma metabolites in Angora goats during mimosine infusion* $\dagger$ (Mean values for four goats with the pooled standard error of the mean)

\begin{tabular}{|c|c|c|c|c|c|c|c|c|c|c|}
\hline \multirow[b]{3}{*}{ Item } & & & \multirow[b]{3}{*}{ MI } & \multirow{2}{*}{\multicolumn{2}{|c|}{ Post }} & \multirow[b]{3}{*}{ SEM } & \multicolumn{4}{|c|}{ Contrast } \\
\hline & \multicolumn{2}{|c|}{ Pre } & & & & & \multirow{2}{*}{\multicolumn{2}{|c|}{$\begin{array}{c}\text { PRC } \\
+ \text { PRS } \\
v . \\
\text { MI }\end{array}$}} & \multirow{2}{*}{$\begin{array}{c}\text { PRC } \\
+ \text { PRS } \\
v . \\
\text { PSS }\end{array}$} & \multirow{2}{*}{$\begin{array}{c}\text { PRC } \\
+ \text { PRS } \\
v . \\
\text { PSC }\end{array}$} \\
\hline & PRC & PRS & & PSS & PSC & & & & & \\
\hline Glucose (mmol/l) & 3.21 & $3 \cdot 40$ & 4.05 & $4 \cdot 28$ & 3.52 & 0.43 & NS & 0.026 & 0.01 & NS \\
\hline NEFA $(\mathrm{mmol} / \mathrm{l})$ & $226 \cdot 4$ & 247.2 & 421.8 & $368 \cdot 5$ & 367.8 & 35.88 & NS & 0.001 & 0.001 & 0.001 \\
\hline Creatinine (mg/l) & $9 \cdot 1$ & $6 \cdot 4$ & $6 \cdot 2$ & $5 \cdot 2$ & $4 \cdot 2$ & 0.39 & 0.001 & 0.02 & 0.02 & 0.02 \\
\hline
\end{tabular}

PRC, pre-infusion control $(-36,-24 \mathrm{~h})$; PRS, pre-infusion saline $(-12,0 \mathrm{~h})$; MI, mimosine infusion (12-72 h); PSS, post-infusion saline $(84-96 \mathrm{~h})$; PSC, post-infusion control $(108,136 \mathrm{~h})$; NEFA, non-esterified fatty acids.

* Infusion of mimosine ( $40 \mathrm{mg} / \mathrm{kg} \mathrm{W}^{0.75}$ per d) to the superficial branch of the deep circumflex iliac artery was started at $0 \mathrm{~h}$ and ceased at $72 \mathrm{~h}$.

$\dagger$ Due to lack of a local response to mimosine only data from the treated side were used.

Table 4. Concentrations of hormones in the plasma of Angora goats during mimosine infusion*†

(Mean values for four goats with the pooled standard error of the mean)

\begin{tabular}{|c|c|c|c|c|c|c|}
\hline Item & PRS & MI & PSC & SEM & PRS v. MI & PRS $y$, PSC \\
\hline Insulin $(\mu \mathrm{IU} / \mathrm{ml})$ & $28 \cdot 7$ & $17 \cdot 3$ & 35.9 & 1.89 & 0.01 & NS \\
\hline Cortisol $(\mu \mathrm{g} / 1)$ & 14 & 62 & 15 & 3.5 & 0.001 & NS \\
\hline Triiodothyronine (ng/l) & 1495 & 695 & 1196 & $43 \cdot 1$ & 0.001 & 0.01 \\
\hline Thyroxine $(\mu \mathrm{g} / 1)$ & $61 \cdot 5$ & $19 \cdot 5$ & 43 & $1 \cdot 8$ & 0.001 & NS \\
\hline
\end{tabular}

PRS, pre-infusion saline $(-12,0 \mathrm{~h}) ; \mathrm{Ml}$, mimosine infusion $(12-72 \mathrm{~h}) ;$ PSC, post-infusion control (108, $136 \mathrm{~h})$.

* Infusion of mimosine $\left(40 \mathrm{mg} / \mathrm{kg} \mathrm{W}^{0.75}\right.$ per $\left.\mathrm{d}\right)$ to the superficial branch of the deep circumflex iliac artery was started at $0 \mathrm{~h}$ and ceased at $72 \mathrm{~h}$.

$\dagger$ Due to lack of a local response to mimosine only data from the treated side were used.

Similar patterns were also observed for plasma mineral concentrations (Table 6, Fig. 3). Plasma glucose level increased during MI and PSS periods contrary to that observed in response to starvation or reduced feed intake (Hayden et al. 1993; Norton et al. 1993). It is not known why plasma creatinine concentrations (Table 3) were higher before mimosine infusion (PRC period); however, there were no observed changes in plasma creatinine during or after mimosine infusion. In animals undergoing starvation plasma creatinine has been shown to be correlated with the nutritional status (energy and protein) of the animal (Muhlbauer \& Oswald, 1992). It was suspected that mimosine may elevate plasma metabolites as a result of decreased water intake and increased urinary excretion. Previous studies in our laboratory have shown that packed cell volume increases as a result of infusing mimosine or feeding Leucaena (T. Sahlu, S. G. Pierzynowski and R. Puchała, unpublished results).

In the present study plasma concentrations of $\mathrm{Zn}$ and $\mathrm{Mg}$ decreased during mimosine infusion (Table 6; Fig. 3). Plasma concentrations of $\mathrm{Mg}$ and $\mathrm{Zn}$ are reliable indicators of $\mathrm{Mg}$ and $\mathrm{Zn}$ deficiencies (Lamand et al. 1983). The decrease in plasma $\mathrm{Zn}$ was similar to that 
Table 5. Concentration ( $\mu$ mol/l) of plasma amino acids of Angora goats during mimosine infusion*†

(Mean values for four goats with the pooled standard error of the mean)

\begin{tabular}{|c|c|c|c|c|c|c|c|c|c|c|}
\hline \multirow[b]{3}{*}{ Item } & & & \multirow[b]{3}{*}{ MI } & & & \multirow[b]{3}{*}{ SEM } & \multicolumn{4}{|c|}{ Contrast } \\
\hline & \multicolumn{2}{|c|}{ Pre } & & \multicolumn{2}{|c|}{ Post } & & \multirow{2}{*}{$\begin{array}{c}\text { PRC } \\
v . \\
\text { PRS }\end{array}$} & \multirow{2}{*}{$\begin{array}{c}\text { PRC } \\
+ \text { PRS } \\
v . \\
\text { MI }\end{array}$} & \multirow{2}{*}{$\begin{array}{c}\text { PRC } \\
+ \text { PRS } \\
v . \\
\text { PSS }\end{array}$} & \multirow{2}{*}{$\begin{array}{c}\text { PRC } \\
+ \text { PRS } \\
\nu . \\
\text { PSC }\end{array}$} \\
\hline & PRC & PRS & & PSS & PSC & & & & & \\
\hline Gilu & $43 \cdot 2$ & $44 \cdot 2$ & 27.0 & 46.9 & 64.9 & $2 \cdot 48$ & NS & 0.001 & NS & 0.02 \\
\hline Ser & $150 \cdot 7$ & $140 \cdot 1$ & $50 \cdot 8$ & 92.5 & $104 \cdot 5$ & $5 \cdot 30$ & NS & 0.001 & 0.02 & 0.02 \\
\hline Gly & $810 \cdot 3$ & $785 \cdot 5$ & 364.6 & 858.6 & $785 \cdot 5$ & $35 \cdot 33$ & NS & 0.001 & NS & NS \\
\hline Ala & 197.9 & $178 \cdot 4$ & 113.4 & 197.9 & $212 \cdot 2$ & $8 \cdot 77$ & NS & 0.001 & NS & NS \\
\hline Arg & $147 \cdot 2$ & $154 \cdot 8$ & $68 \cdot 8$ & 163.4 & $127 \cdot 3$ & $14 \cdot 6$ & NS & 0.001 & NS & 0.01 \\
\hline Tyr & $73 \cdot 2$ & $70-4$ & $54 \cdot 8$ & 64.5 & $67 \cdot 7$ & $4 \cdot 87$ & NS & 0.01 & NS & NS \\
\hline Val & $257 \cdot 7$ & $253 \cdot 7$ & $97 \cdot 7$ & $180 \cdot 6$ & $207 \cdot 2$ & $8 \cdot 48$ & NS & 0.001 & 0.01 & 0.01 \\
\hline Phe & $53 \cdot 2$ & $56 \cdot 1$ & $51 \cdot 2$ & $56 \cdot 4$ & $50 \cdot 7$ & 1.63 & NS & NS & NS & NS \\
\hline Ile & 87.9 & 91.4 & $31 \cdot 1$ & $59 \cdot 1$ & 71.0 & 3.91 & NS & 0.001 & 0.01 & NS \\
\hline Leu & $216 \cdot 3$ & $198 \cdot 3$ & $74 \cdot 4$ & $128 \cdot 7$ & $123 \cdot 7$ & $8-86$ & NS & 0.001 & 0.02 & 0.02 \\
\hline Lys & 95.9 & $93 \cdot 1$ & $37 \cdot 4$ & 72.9 & 94.8 & $4 \cdot 28$ & NS & 0.001 & NS & NS \\
\hline Met & $22 \cdot 7$ & $21 \cdot 7$ & $13 \cdot 1$ & $20 \cdot 3$ & $22 \cdot 1$ & $1 \cdot 41$ & NS & 0.001 & NS & NS \\
\hline
\end{tabular}

PRC, pre-infusion control $(-36,-24 \mathrm{~h})$; PRS, pre-infusion saline $(-12,0 \mathrm{~h})$; MI, mimosine infusion $(12-72 \mathrm{~h})$; PSS, post-infusion saline $(84-96 \mathrm{~h})$; PSC, post-infusion control $(108,136 \mathrm{~h})$.

* Infusion of mimosine $\left(40 \mathrm{mg} / \mathrm{kg} \mathrm{W}^{0.75}\right.$ per d) to the superficial branch of the deep circumflex iliac artery was started at $0 \mathrm{~h}$ and ceased at $72 \mathrm{~h}$.

$\dagger$ Due to lack of a local response to mimosine only data from the treated side were used.

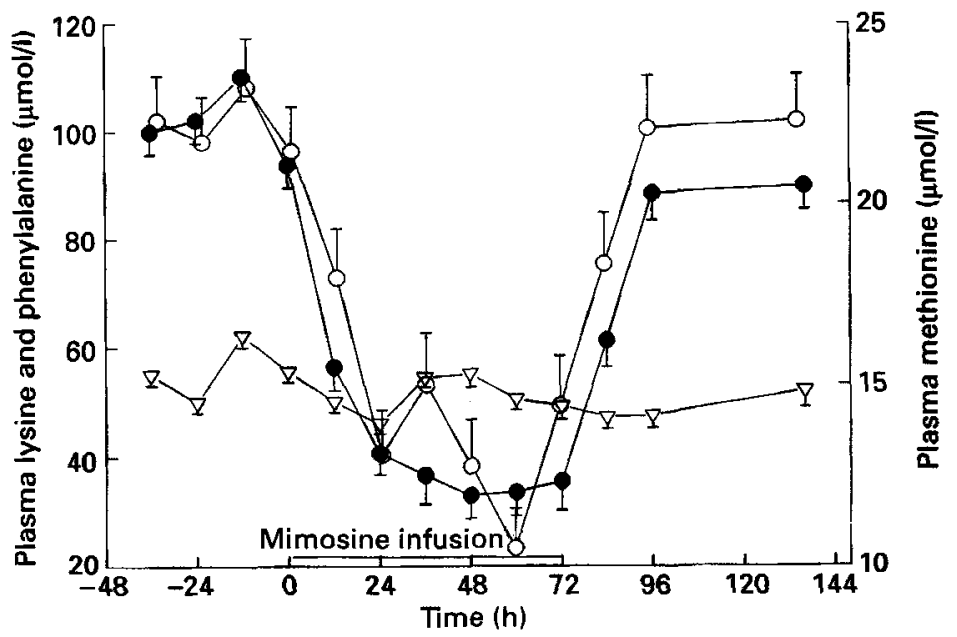

Fig. 2. Plasma lysine $(O)$, phenylalanine $(\nabla)$ and methionine $(O)$ concentrations $(\mu \mathrm{mol} / \mathrm{l})$ during mimosine infusion $\left(40 \mathrm{mg} / \mathrm{kg} \mathrm{W}^{0-75}\right.$ per d) to the superficial branch of the deep circumflex iliac artery in Angora goats. Values are means for four goats, with their standard errors indicated by vertical bars.

observed when ewes were fed on diets containing only $10 \%$ of their $\mathrm{Zn}$ requirement (Masters \& Moir, 1983). However, in the present experiment the time required to decrease plasma $\mathrm{Zn}$ was much shorter ( $2 \mathrm{~d} v$. 10 weeks). It should also be noted that the average daily $\mathrm{Zn}$ intake in our experiment was $71 \mathrm{mg} / \mathrm{d}$ compared with $3.5 \mathrm{mg} / \mathrm{d}$ in the work of Masters 


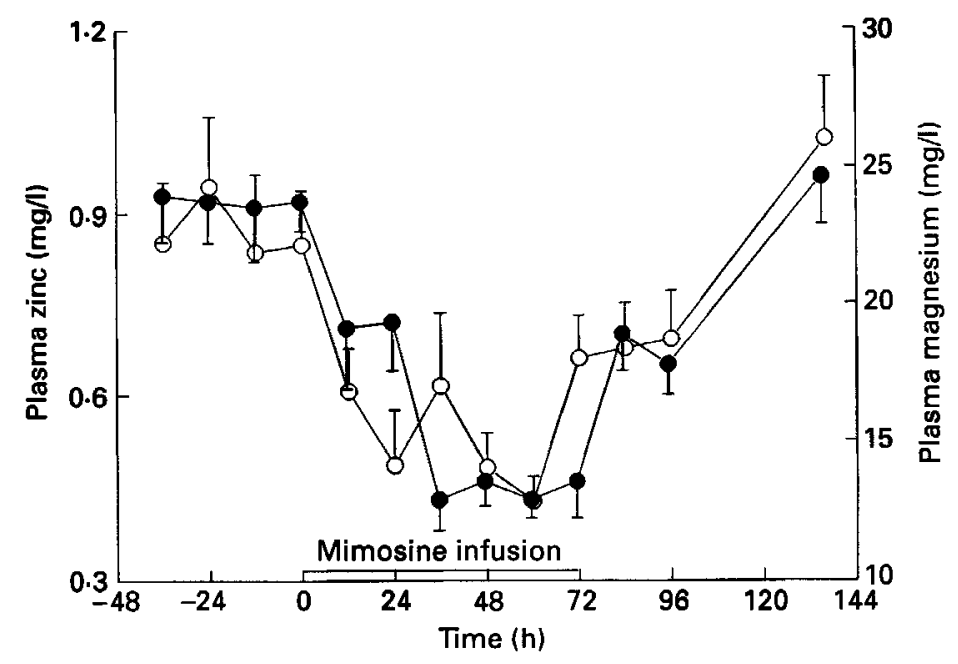

Fig. 3. Plasma zinc $(O)$ and magnesium $(O)$ concentrations $(\mathrm{mg} / \mathrm{l})$ during mimosine infusion $(40 \mathrm{mg} / \mathrm{kg} \mathrm{W}$ per d) to the superficial branch of the deep circumflex iliac artery in Angora goats. Values are means for four goats, with their standard errors indicated by vertical bars.

Table 6. Concentrations ( $m g / l)$ of plasma minerals in Angora goats during mimosine infusion* $\dagger$

(Mean values for four goats with the pooled standard error of the mean)

\begin{tabular}{|c|c|c|c|c|c|c|c|c|c|c|}
\hline \multirow[b]{3}{*}{ Item } & & & \multirow[b]{3}{*}{ MI } & & & & \multicolumn{4}{|c|}{ Contrast } \\
\hline & \multicolumn{2}{|c|}{ Pre } & & \multicolumn{2}{|c|}{ Post } & \multirow[b]{2}{*}{ SEM } & \multirow{2}{*}{$\begin{array}{c}\text { PRC } \\
v . \\
\text { PRS }\end{array}$} & \multirow{2}{*}{$\begin{array}{c}\text { PRC } \\
+ \text { PRS } \\
v . \\
\text { MI }\end{array}$} & \multirow{2}{*}{$\begin{array}{c}\text { PRC } \\
\text { + PRS } \\
v . \\
\text { PSS }\end{array}$} & \multirow{2}{*}{$\begin{array}{c}\text { PRC } \\
+ \text { PRS } \\
v . \\
\text { PSC }\end{array}$} \\
\hline & PRC & PRS & & PSS & PSC & & & & & \\
\hline Zinc & 0.97 & 0.91 & 0.49 & 0.67 & 0.95 & 0.063 & NS & 0.001 & 0.01 & NS \\
\hline Magnesium & $21 \cdot 4$ & $22 \cdot 1$ & $14 \cdot 6$ & 23.9 & $23 \cdot 0$ & $1 \cdot 74$ & NS & $0 \cdot 01$ & NS & NS \\
\hline Iron & $2 \cdot 28$ & $2 \cdot 40$ & $2 \cdot 27$ & 2.94 & $2 \cdot 66$ & 0.670 & NS & NS & NS & NS \\
\hline Copper & $2 \cdot 51$ & $2 \cdot 64$ & $2 \cdot 24$ & $2 \cdot 64$ & $2 \cdot 93$ & 0.259 & NS & NS & NS & NS \\
\hline
\end{tabular}

PRC, pre-infusion control $(-36,-24 \mathrm{~h})$; PRS, pre-infusion saline $(-12,0 \mathrm{~h})$; $\mathrm{MI}$, mimosine infusion (12-72 h); PSS, post-infusion saline (84-96 h); PSC, post-infusion control (108, $136 \mathrm{~h})$.

* Infusion of mimosine ( $40 \mathrm{mg} / \mathrm{kg} \mathrm{W}^{0.75}$ per d) to the superficial branch of the deep circumflex iliac artery was started at $0 \mathrm{~h}$ and ceased at $72 \mathrm{~h}$.

$\uparrow$ Due to lack of a local response to mimosine only data from the treated side were used.

\& Moir (1983). Therefore it is most likely that changes in plasma $\mathrm{Zn}$ were caused by mimosine infusion. Furthermore, lack of changes in plasma $\mathrm{Cu}$ and $\mathrm{Fe}$ concentrations support the concept that mimosine was responsible for the changes in plasma $\mathrm{Zn}$ and $\mathrm{Mg}$ (Tables 2 and 6; Fig. 3).

It is very difficult to relate these occurrences to the clinical symptoms of mineral deficiencies. Changes in plasma mineral concentrations occurring during mimosine infusion would not be expected to be comparable to changes caused by dietary deficiency. The decreases in plasma mineral concentrations and their return to original values were sudden in this experiment. Therefore reduced mineral concentrations may have altered several enzyme systems (Couinaud, 1984) which would not necessarily be manifested as 
clinical mineral deficiency symptoms. The only observed symptom that could be related to $\mathrm{Zn}$ deficiency was increased salivation.

The chelating property of mimosine is the basis for its use as a drug for treating Feoverloading in humans (McLaren et al. 1983; Forsbeck et al. 1987; Brock et al. 1988). Mimosine, also, is thought to form $\mathrm{Zn}, \mathrm{Mg}$ and $\mathrm{Cu}$ complexes (Schmid, 1988; Kontoghiorghes, 1990). In the presence of mimosine these metal ions are excreted, chelated with mimosine, via the kidney in proportion to the dose of mimosine (Schmid, 1988). The studies of Watson et al. (1991) and Mosca et al. (1992) indirectly support the hypothesis that the primary effect of mimosine is depletion of metabolic trace elements in the body. These authors demonstrated reversible inhibition of cell cycle progression by the addition of mimosine to mammalian cell cultures. Mosca et al. (1992) concluded that cell arrest was due to inhibition of DNA replication and that mimosine inhibits DNA synthesis possibly by inhibiting metal-dependent enzymes involved in DNA replication.

Some nutritional studies suggest that mimosine can chelate metals or can cause mineral deficiencies. The mimosine content of Leucaena meal was reported to be reduced by treating it with a solution of $\mathrm{FeSO}_{4}(12.6 \mathrm{~g} / \mathrm{kg}$ Leucaena) (Sunaria \& Vidya-Sagar, 1989). Prasad (1989) observed that goats became anorexic, weak, developed frothing and erosive lesions in the mouth and had rough coats when given a ration containing $50-75 \%$ Leucaena. Clinical improvement, without a change of diet, was achieved by giving $2.0 \mathrm{~g}$ of a mineral mixture (equal parts of $\mathrm{Zn}, \mathrm{Cu}$ and $\mathrm{Fe}$ )/d.

Urinary excretion of mimosine was not measured in the present study since that was not the objective of the experiment and it was expected that mimosine would cause changes in skin metabolism and mohair measurements. However, in another study (Puchala et al. $1995 b$ ) urinary excretion of the mimosine metabolite 2,3-dihydroxypyridine (2,3-DHP) was much faster when goats received 2,3-DHP with a mineral mixture ( $\mathrm{Zn}, \mathrm{Mg}, \mathrm{Fe}$ ) intraruminally compared with 2,3-DHP alone. Approximately $67 \%$ of intraruminally injected DHP was excreted during the first $24 \mathrm{~h}$ by the group administered DHP plus minerals compared with $30 \%$ by the group without the minerals. DHP toxicity was only observed in the group that received DHP alone. It could, therefore, be concluded that providing minerals to chelate 2,3-DHP increased the rate of toxin removal from the body.

Decreased feed intake or decreased plasma $\mathrm{Zn}$ concentration may have contributed, also, to changes in plasma hormones. A decrease in $\mathrm{Zn}$ concentration occurred during mimosine infusion (Fig. 3) and corresponded with a decrease in insulin and an increase in cortisol (Table 4). Insulin is associated with $\mathrm{Zn}$ in the secretory vesicles of the pancreas (Roth \& Kirchgessner, 1981). A decrease in plasma $\mathrm{Zn}$ concentration may affect this association and thus alter insulin storage and release. Jhala \& Baly (1991) using an isolated perfused pancreas technique showed that $\mathrm{Zn}$ deficiency decreased insulin secretion. The increase in plasma cortisol may also be due to a decrease in plasma $\mathrm{Zn}$ concentration. DepasqualeJardieu \& Fraker (1979) demonstrated that Zn deficiency increased the plasma cortisol level.

There was no local effect of mimosine as infused mimosine did not produce changes in skin preparations. Animals did not lose mohair in the perfused area or any other region of the body; however, changes in metabolism related to mimosine or Leucaena toxicity were observed. It is hypothesized that hair loss in sheep observed by others (Reis, 1978; Hoey \& Hopkins, 1983) was due to the different characteristics of mohair and wool follicles (Reis \& Sahlu, 1994). Decreased plasma $\mathrm{Zn}$ and $\mathrm{Mg}$ concentrations appear to be the primary mechanism of mimosine toxicity. It is suggested that the chelating property of mimosine is responsible for decreased plasma $\mathrm{Zn}$ and $\mathrm{Mg}$ concentrations. Chelating with metals may be essential for effective toxin removal by the kidney (Schmid, 1988). 
This work was supported by United States Department of Agriculture Grant No. 9138814-6240 and PCE-5053-G-00-3066-00. The authors wish to thank the farm crew at the E. (Kika) de la Garza Institute for Goat Research for animal care.

\section{REFERENCES}

American Society for Testing and Materials (1988). Standard test method D2130. Wool content of raw wool, laboratory scale. Annual Book of ASTM Standards, pp. 335-365. Philadelphia: American Society for Testing and Materials.

Brock, J. H., Liceaga, J. \& Kontoghiorghes, G. J. (1988). The effect of synthetic iron chelators on bacterial growth in human serum. Microbiology and Immunology 1, 55-60.

Couinaud, C. (1984). Le zinc. Journal of Chiropractic, Paris 121, 611-621.

Crounse, R. G., Maxwell, J. D. \& Blank, H. (1962). Inhibition of growth of hair by mimosine. Nature 194, 694-695.

Depasquale-Jardieu, P. \& Fraker, P. J. (1979). The role of corticosterone in the loss in immune function in the zinc-deficient A/J mouse. Journal of Nutrition 109, 1847-1855.

El-Harith, E. A., Hiller, A. \& Meulen, U. (1983). The effect of administration of glycine and tyrosine on the growth depression caused by mimosine in rats. Journal of Animal Physiology and Animal Nutrition 50, 132-137.

El-Harith, E. A., Mohme, H., Meulen, U., Bartha, M. \& Gunther, K. D. (1981). Effects of mimosine on some serum enzyme activities and amino acid metabolism in the rat. Journal of Animal Physiology and Animal Nutrition 46, 255-263.

Fernandez, J. M., Sahlu, T., Lu, C. D. \& Akinsoyinu, A. O. (1991). Mimosine administration in goats: effects on lactational performance and metabolism in early Alpine lactating does. Journal of Animal Science 69, Suppl. 1, 392 Abstr.

Forsbeck, K., Nilsson, K. \& Kontoghiorghes, G. J. (1987). Variation in iron accumulation, transferrin membrane binding and DNA synthesis in the K-562 and U-937 cell lines induced by chelators and their iron complexes. European Journal of Haematology 39, 318-325.

Franzolin, N. R. \& Velloso, L. (1986). Leucaena leucocephala (Lam.) de Wit em racoes para ovinos. 2. Toxicidade (Leucaena leucocephala (Lam.) in diets for sheep. 2. Toxicity). Revista da Sociedade Brasileira de Zootecnia 15, $415-424$

Hayden, J. M., Williams, J. E. \& Collier, R. J. (1993). Plasma growth hormone, insulin-like growth factor, insulin, and thyroid hormone association with body protein and fat accretion in steers undergoing compensatory gain after dietary energy restriction. Journal of Animal Science 77, 3327-3338.

Hegarty, M. P. (1978). Toxic amino acids of plant origin. In Effects of Poisonous Plants on Livestock, pp. 575-585 [R. F. Keller, K. R. van Kampen and J. F. Lynn editors]. New York: Academic Press.

Hegarty, M. P., Lee, C. P., Christie, G. S., De Munk, F. G. \& Court, R. D. (1978). Comparative toxicities of mimosine and some chemically related compounds to mouse bone marrow cells in liquid culture. Australian Journal of Biological Sciences 31, 27-40.

Hoey, W. A. \& Hopkins, P. S. (1983). Chronic arterial cannulation for studying the skin of sheep. Research in Veterinary Science 35, 247-249.

Jacquemet, N., Fernandez, J. M., Sahlu, T. \& Lu, C. D. (1990). Mohair quality and metabolic profile of Angora goats during acute minosine toxicity. Journal of Animal Science 68, Suppl. 1, 400 Abstr.

Jhala, U. S. \& Baly, D. L. (1991). Zinc deficiency results in a post transcriptional impairment in insulin synthesis. FASEB Journal 5, A941 Abstr.

Jones, R. J. \& Hegarty, M. P. (1984). The effect of different proportions of Leucaena leucocephala in the diet of cattle on growth, feed intake, thyroid function and urinary excretion of dihydroxypyridine. Australian Journal of Agricultural Research 35, 317-320.

Kontoghiorghes, G. J. (1990). Chelators affecting iron absorption in mice. Arzneumittelforschung 40, 1332-1335.

Lamand, M., Lab, C., Mignon, M. \& Tressol, J. C. (1983). A zinc-deficient diet for ruminants: diagnosis and treatment of deficiency. Annales de Recherches Vétérinaires 4, 211-215.

McLaren, G. D., Muir, W. A. \& Kellermeyer, R. W. (1983). Iron overload disorders: natural history, pathogenesis, diagnosis, and therapy. Critical Reviews in Clinical and Laboratory Sciences 19, 205-266.

Masters, D. G. \& Moir, R. J. (1983). Effect of zinc deficiency on the pregnant ewe and developing foetus. British Journal of Nutrition 49, 365-372.

Mosca, P. J., Dijkwel, P. A. \& Hamlin, J. L. (1992). The plant amino acid mimosine may inhibit initiation at origins of replication in Chinese hamster cells. Molecular and Cellular Biology 12, 4375-4383.

Muhlbauer, B. \& Osswald, H. (1992). Feeding but not salt loading is the dominant factor controlling urinary dopamine excretion in conscious rats. Naunyn Schmiedebergs Archiv Pharmacology 364, 469-471.

Norton, P., Falciglia, G. \& Gist, D. (1993). Physiologic control of food intake by neural and chemical mechanisms. Journal of the American Dietetic Association 93, 450-457.

Pierzynowski, S. G., Sahlu, T., Puchała, R., Hart, S. P. \& A1-Dehneh, A. (1994). Local infusion of glucose and insulin in isolated skin perfusion sites in Angora goats. Small Ruminant Research 14, 137-141. 
Prasad, J. (1989). A note on toxic effects of Leucaena leucocephala in goats: a clinical study. Indian Journal of Veterinary Medicine 9, 151-152.

Puchała, R., Pierzynowski, S. G., Sahlu, T. \& Hart, S. P. (1995a). Effects of amino acids administered to a perfused area of the skin in Angora goats. Journal of Animal Science 73, 565-570.

Puchała, R., Sahlu, T., Davis, J. J. \& Hart, S. P. (1995b). Influence of mineral supplementation on 2,3dihydroxypyridine toxicity in Angora goats. Animal Feed Science and Technology 55, 253-262.

Reis, P. J. (1978). Effectiveness of intravenous and abomasal doses of mimosine for defleecing sheep and effects on subsequent wool growth. Australian Jotrnal of Agricultural Research, 1043-1055.

Reis, P. J. \& Sahlu, T. (1994). The nutritional control of the growth and properties of mohair and wool fibers: a comparative review. Journal of Animal Science 72, 1899-1910.

Reisner, A. H., Bucholtz, C. A. \& Ward, K. A. (1979). Effect of the plant amino acid mimosine on cell division, DNA, RNA and protein synthesis in Paramecium. Molecular Pharmacology 16, 278-286.

Roth, H. P. \& Kirchgessner, M. (1981). Zinc and insulin metabolism. Biological Trace Element Research 3,13-32.

Sahlu, T., Fernandez, J. M., Lu, C. D. \& Manning, R. (1992). Dietary protein level and ruminal degradability for mohair production in Angora goats. Journal of Animal Science 70, 1526-1533.

Schmid, H. (1988). Untersuchungen zum toxikologischen Wirkungsmechanismus von Mimosin (Investigations into the toxicological mechanisms of mimosine). Inaugural-Dissertation. Tierarztliche Fakultat der LudwigMaximilians-Universităt, München, Germany.

Seeley, R. C. \& Kinsey, W. J. (1982). The Determination of Trace Elements in Whole Blood by DC Plasma Emission Spectroscopy. Haverhill, MA: Spectra Metrics/Beckman Instruments.

Statistical Analysis Systems (1985). User's Guide: Statistics. Cary, NC: SAS Institute Inc.

Steel, R. G. D. \& Torrie, J. A. (1980). Principles and Procedures of Statistics. New York: McGraw-Hill Book Co. Inc.

Sunaria, K. R. \& Vidya-Sagar, V. (1989). Subabul (Leucaena leucocephala) leaf meal - its chemical composition, amino acid make up and detoxification of mimosine and tannins. Indian Journal of Animal Nutrition 6, 223-226.

Szyszka, M. \& Meulen, U. (1984). Die Bestimmung der biologischen Halbwertszeit für Mimosin von Ratten (The measurement of the biological half-life of mimosine in rats). Zeitschrift Tierarztliche Wochenschrift 91, $262-264$.

Szyszka, M. \& Meulen, U. (1985). Das Verhalten von Schafen gegenüber dem toxischen Mimosin in Leucaena leucocephala (The behavioural response of sheep to the toxin mimosine in Leucaena leucocephala). Journal of Animal Physiology and Animal Nutrition 53, 65-69.

Tangendjaja, B. \& Willis, R. B. H. (1980). Analysis of mimosine and 3-hydroxy-4(1H)-pyridone by highperformance liquid chromatography. Journal of Chromatography 202, 317-318.

Thompson, J. F., Morris, C. L. \& El-Harith, E. A. (1969). The naturally occurring amino acids. Review in Biochemistry 38, 137-158.

Tsai, W. C. (1961). The effect of mimosine on several enzymes. Formosan Medical Association 60, 58-64.

Unterhalt, B. (1980). Toxische Aminosauren und Proteine in Pflanzen (Toxic amino acids and proteins in plants). Deutsche Apotheker Zeitung 24, $1093-1094$.

Ward, K. A. \& Harris, R. L. N. (1976). Inhibition of wool follicle DNA synthesis by mimosine and related $4(1 \mathrm{H})-$ pyridones. Australian Journal of Biological Sciences 29, 189-196.

Watson, P. A., Hanauske-Abel, H. H., Flint, A. \& Lalande, M. (1991). Mimosine reversibly arrests cell cycle progression at the G1-S phase border. Cytometry 12, 242-246. 